ISSN $1978-3000$

\title{
Uji Kemampuan Alang-alang (Imperata cylindrica) sebagai Bahan Penutup Alas Kandang Broiler
}

\author{
Utilization of Imperata cylindrica as litter substitution of Broiler Chickens
}

\author{
Hardi Prakoso \\ Jurusan Peternakan, Fakultas Pertanian, Universitas Bengkulu, Bengkulu \\ Jalan Raya Kandang Limun, Bengkulu, Telp (0736) 21170 Pst 219.
}

\begin{abstract}
Postal cage has been frequently causing negative effects on chickens performance for direct contact to wet and unpleasant smell of litter. The condition has led to an uncomfortable environment for the chickens as well as respiration disorder which causes bad performance on chickens. Therefore, the cages should be completed with litter. The aim of this research was to investigate the use of Imperata cylindrica as litter substitution of broiler chickens. One hundred twenty day old broiler chickens were distributed into two treatments groups. The treatments were three levels of litter thickness $(4 \mathrm{~cm}, 7 \mathrm{~cm}$, and $10 \mathrm{~cm})$ with 4 replications. The observations were conducted each week for five weeks. Variables measured were temperature of litter, litter water content and weight gain. The collected data were analyzed by using Completely Randomized Design. Results showed that Imperata cylindrica as litter highly significantly affected litter temperature and litter water content; however, the treatments did not significantly affect weight gain. Overall, Imperata cylindrica is a potential source to substitute rice husk as litter.
\end{abstract}

Key words: rice husk, Imperata cylindrica, litter, temperature, water content, weight gain.

\begin{abstract}
ABSTRAK
Kandang system postal sering menimbulkan dampak buruk pada ayam, kerena kontak langsung dengan litter yang basah dan bau. Kondisi yang demikian menjadikan broiler tidak nyaman, dan mengalami gangguan pernafasan. Kemudian pada gilirannya performans ayam menjadi menurun. Guna mengatasi dampak negatip tersebut, maka alas kandang perlu diberi bahan penutup (litter). Penelitian ini berupaya menggantikan sekam padi dengan alang-alang sebagai bahan penutup alas kandang broiler. 120 ekor anak ayam broiler umur tujuh hari (satu minggu) secara acak dialokasikan ke dalam dua perlakuan sekam padi dan alang-alang, sebagai bahan penutup alas kandang broiler. Setiap perlakuan digunakan tiga aras ketebalan sebesar empat, tujuh, dan $10 \mathrm{~cm}$., dan masing-masing perlakuan diulang sebanyak empat kali. Pengamatan dilakukan selama lima minggu, dan pengumpulan data dilakukan setiap minggu. Variabel yang diukur terdiri dari temperatur litter, kadar air litter, dan pertambahan berat badan broiler. Data yang diperoleh dianalisis dengan Rancangan Acak Lengkap (RAL). Hasil penelitian menunjukkan bahwa alang-alang sebagai bahan penutup alas kandang broiler berbeda sangat nyata lebih tinggi terhadap temperatur litter dan kadar air litter, tetapi berbeda tidak nyata terhadap rataan pertambahan berat badan, bila dibandingkan dengan sekam padi. Dapat disimpulkan bahwa alang-alang dapat menggantikan sekam padi sebagai penutup alas kandang broiler.
\end{abstract}

Kata Kunci : Alas kandang, Litter, Sekam Padi, Alang-alang, Temperatur Litter, Kadar Air Litter, Pertambahan Berat Badan 


\section{PENDAHULUAN}

Alas kandang mempunyai peranan yang sangat penting dalam satu sistem management kandang broiler. Alas kandang selain sebagai tempat berpijak broiler, terlebih penting lagi sebagai pengendali kandungan udara yang terdapat di dalam kandang. Kandungan udara dalam kandang menentukan kesehatan ternak, yang pada akhirnya menentukan keuntungan peternak. Oleh karena itu mutlak diperlukan pengendalian kandungan udara di dalam kandang.

Kandang system postal sering menimbulkan dampak buruk pada ayam, karena kontak langsung dengan litter yang basah dan bau. Kondisi yang demikian menjadikan broiler tidak nyaman, dan mengalami gangguan pernafasan. Kemudian pada gilirannya performans ayam menjadi menurun. Arifien (2003) menyatakan, litter merupakan tempat bibit penyakit berkembang biak dan sebagai sumber gas beracun, seperti asam sulfida $\left(\mathrm{H}_{2} \mathrm{~S}\right)$ dan amoniak. Guna mengurangi gas beracun tersebut, maka alas kandang system postal ditutupi suatu bahan. Sarwono (2002) menyatakan, bahwa bahan yang dapat digunakan sebagai alas kandang harus memenuhi standar, kandungan air tidak boleh melebihi $25 \%$, tidak menimbulkan debu, mudah menyerap air, mudah diperoleh, dan murah harganya. Penggunaan bahan penutup alas kandang berfungsi mengendalikan iklim mikro. Iklim mikro adalah kondisi iklim pada suatu ruangan yang sangat terbatas, dan sangat penting bagi kehidupan ternak. Iklim mikro dapat berupa suhu udara, kelembaban udara, maupun suhu permukaan tanah (Anonim, 2007). Produksi gas-gas beracun dalam kandang berasal dari feses ayam, yang jatuh ke lantai kandang. Gas-gas beracun ini akan terus bertahan dan berakumulasi selama ternak berada di kandang. Guna menekan dampak negatip dari gas beracun tersebut, teknologi perkandangan telah mengaplikasikan bahan penutup lantai kandang. Umumnya peternak menggunakan sekam padi sebagai bahan penutup lantai kandang. Namun keberadaan sekam padi menjadi semakin sulit didapat, sehingga biaya operasional kandang menjadi tinggi. Di pihak lain alang-alang (Imperata cylindrica) yang keberadaannya sangat banyak dan sebagai gulma tanaman, sampai saat ini belum umum digunakan sebagai alas penutup lantai kandang. Alang-alang mempunyai daya absorbsi yang tinggi (Michael, dkk., 1998), tidak berdebu, dan sangat mudah didapat, oleh karena itu, diduga alangalang dapat menggantikan sekam padi sebagai bahan penutup alas kandang broiler. Penelitian ini bertujuan untuk menguji kemampuan alang-alang sebagai bahan alas kandang broiler menggantikan sekam padi.

\section{MATERI DAN METODE}

120 ekor anak ayam broiler umur tujuh hari (satu minggu) dipelihara selama lima minggu pada 24 petak kandang postal. Setiap petak berukuran $80 \times 80 \times 80$ cm., yang diisi lima ekor anak ayam broiler. Setiap petak dilengkapi alat pemanas (lampu pijar 40 watt), tempat minum botol $500 \mathrm{ml}$., tempat makan botol 1 $\mathrm{kg}$.. Semua ayam mendapat ransum standar komersial broiler starter sampai umur 21 hari, kemudian dilanjutkan ransum standar komersial broiler finisher sampai umur enam minggu.

Petak kandang didistribusikan secara acak pada enam perlakuan masingmasing dengan empat ulangan, menggunakan rancangan acak lengkap (RAL). Sebagai perlakuan adalah sekam padi dan daun alang-alang sebagai 


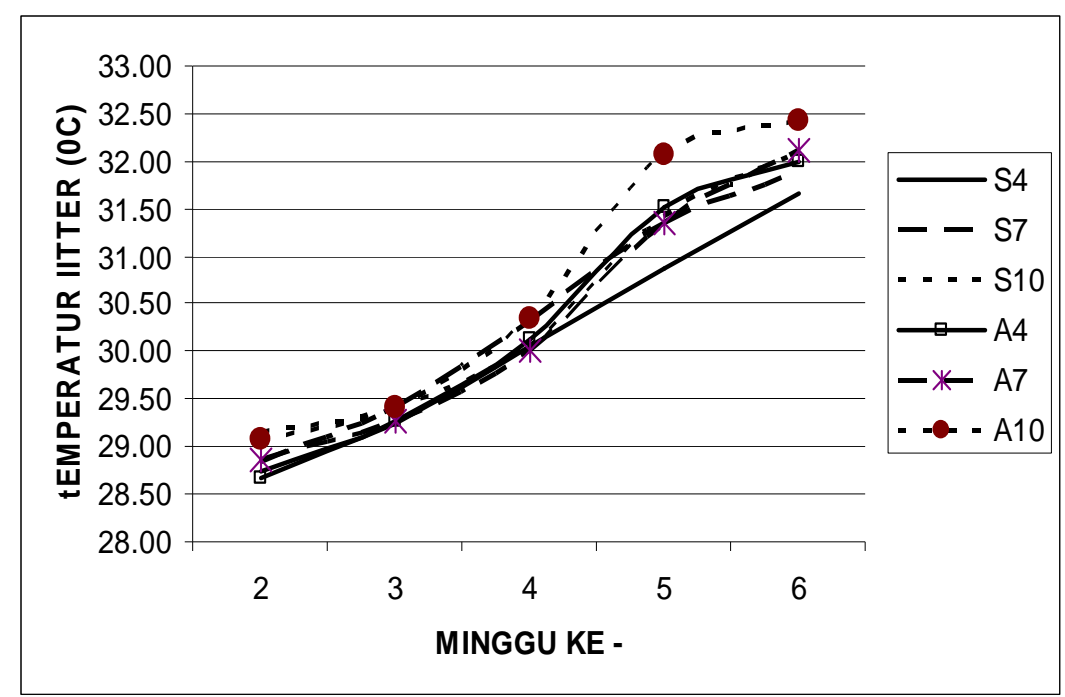

Grafik 1. Peningkatan temperatur litter $\left({ }^{\circ} \mathrm{C}\right)$ berbagai bahan penutup alas kandang berdasarkan umur broiler.

penutup alas petak kandang. Masingmasing perlakuan terdiri dari tiga aras (level) ketebalan empat, tujuh, dan $10 \mathrm{~cm}$. Sekam padi dibeli dari penggilingan padi, dan langsung digunakan sebagai bahan penutup alas kandang sesuai dengan aras perlakuan. Alang-alang diperoleh dari hasil pencabutan di lapangan, dicacah satu centimeter, kemudian dijemur sampai kering.

Variabel pengukuran dilakukan setiap minggu selama lima minggu. Variabel pertambahan berat badan diperoleh dari selisih penimbangan berat badan pada akhir minggu dengan minggu sebelumnya. Variabel temperatur litter diukur menggunakan thermosoil. Variabel kadar air diukur menggunakan moisture meter.
Data perkembangan variable per minggu disajikan secara deskreptif, dan data akhir penelitian dianalisis menggunakan program SPSS.

\section{HASIL DAN PEMBAHASAN}

\section{Pengaruh Perlakuan Terhadap Temperatur Litter}

Temperatur litter dapat mempengaruhi kenyamanan pada broiler. Temperatur litter memberi kontribusi yang sangat besar terhadap akumulasi temperatur kandang. Oleh karena itu perlu diupayakan agar temperatur litter dalam kondisi seoptimal mungkin.

Pengaruh perlakuan terhadap temperatur litter disajikan dalam Grafik 1.

Tabel 1. Pengaruh Perlakuan Terhadap Temperatur Litter pada Akhir Penelitian. $\left({ }^{\circ} \mathrm{C}\right)$

\begin{tabular}{llllll}
\multirow{2}{*}{ Perlakuan } & \multicolumn{6}{c}{ Ulangan } & Rataan \\
\cline { 2 - 5 } & \multicolumn{7}{c}{1} & \multicolumn{2}{c}{3} & \multicolumn{2}{c}{4} & \\
\hline S4 & 31.76 & 31.76 & 31.31 & 31.79 & $31.66^{\mathrm{c}}$ \\
S7 & 30.98 & 31.90 & 32.24 & 32.40 & $31.88^{\mathrm{b}}$ \\
S10 & 32.05 & 32.17 & 32.00 & 32.19 & $32.10^{\mathrm{b}}$ \\
A4 & 32.17 & 31.79 & 31.86 & 32.19 & $32.00^{\mathrm{b}}$ \\
A7 & 31.98 & 32.02 & 32.33 & 32.12 & $32.11^{\mathrm{bc}}$ \\
A10 & 32.38 & 32.31 & 32.47 & 32.55 & $32.43^{\mathrm{a}}$ \\
\hline
\end{tabular}

Ket. : Huruf superscript berbeda pada kolom yang sama

Menunjukkan berbeda sangat nyata $(\mathrm{p}<0,01)$.

S : Sekam Padi, A : Alang-alang 
Grafik 1. memperlihatkan terjadi peningkatan temperatur litter $\left({ }^{\circ} \mathrm{C}\right)$ seiring dengan bertambahnya umur broiler. Nampak pola peningkatan temperatur litter berbagai bahan penutup alas kandang sekam maupun alang-alang seragam, namun perlakuan alang-alang lebih cepat meningkat dibandingkan perlakuan sekam padi. Data menunjukkan bahwa semakin tebal bahan penutup alas lantai memberi kontribusi panas yang lebih tinggi, baik pada awal penggunaannya sampai akhir penggunaannya. Kondisi yang demikian dapat dipahami, karena semakin tebal penutup alas lantai berarti semakin banyak bahan yang digunakan. Bahan organik mempunyai energi, sehingga semakin banyak bahan tersebut, maka semakin tinggi pula energinya, dan pada gilirannya meningkatkan temperatur.

Berdasarkan hasil sidik ragam (Tabel 1) terbukti bahwa perlakuan berpengaruh sangat nyata $(\mathrm{p}<0,01)$ terhadap temperatur litter.

Tabel 1. menunjukkan bahwa, rataan temperatur litter perlakuan alangalang $10 \mathrm{~cm}$ berbeda sangat nyata $(\mathrm{p}<0,01)$ lebih tinggi dibandingkan perlakuan lainnya. Rataan temperatur litter perlakuan alang-alang $7 \mathrm{~cm}$. dengan rataan perlakuan sekam padi 4, 7, dan $10 \mathrm{~cm}$., satu sama lain berbeda tidak nyata $(p>0,01)$. Rataan temperatur litter perlakuan sekam padi 4 $\mathrm{cm}$. sangat nyata lebih rendah $(\mathrm{p}<0,01)$ dibandingkan dengan rataan perlakuan sekam padi 7, 10, dan alang-alang $4 \mathrm{~cm}$. Terbukti bahwa semakin tebal penutup alas kandang, berakibat pada peningkatan temperature litter. Berdasarkan pembahasan tersebut dapat ditarik kesimpulan bahwa penggunaan alangalang sebagai penutup alas kandang berpengaruh sangat nyata meningkatkan temperatur litter.

\section{Pengaruh Perlakuan Terhadap Kadar Air Litter}

Kadar air yang tinggi pada litter merupakan media yang sangat baik untuk tumbuh kembangnya mikro organisme. Oleh karena itu kadar air dalam litter sangat mempengaruhi kesehatan ternak. Perkembangan peningkatan kadar air litter akibat perlakuan, disajikan pada Grafik 2.

Grafik 2. memperlihatkan terjadi peningkatan kandungan kadar air litter yang sangat cepat dari awal penggunaannya. Kondisi tersebut disebabkan bahan yang digunakan sangat respon dalam menyerap air. Semakin lama digunakan bahan menjadi semakin jenuh, sehingga mempunyai kemampuan yang

Tabel 2. Pengaruh Perlakuan Terhadap Rataan Kadar Air pada Akhir Penelitian (\%)

\begin{tabular}{lrrrrr}
\hline \multirow{2}{*}{ Perlakuan } & \multicolumn{5}{c}{ Ulangan } \\
\cline { 2 - 5 } & 1.00 & 2.00 & 3.00 & 4.00 & \\
\hline S4 & 31.76 & 31.76 & 31.31 & 31.79 & $31.66^{\mathrm{b}}$ \\
S7 & 30.98 & 31.90 & 32.24 & 32.40 & $31.88^{\mathrm{b}}$ \\
S10 & 32.05 & 32.17 & 32.00 & 32.19 & $32.10^{\mathrm{b}}$ \\
A4 & 32.17 & 31.79 & 31.86 & 32.19 & $32.00^{\mathrm{a}}$ \\
A7 & 31.98 & 32.02 & 32.33 & 32.12 & $32.11^{\mathrm{a}}$ \\
A10 & 32.38 & 32.31 & 32.47 & 32.55 & $32.43^{\mathrm{a}}$ \\
\hline
\end{tabular}

Ket. : : Huruf superscript berbeda pada kolom yang sama

Menunjukkan berbeda sangat nyata $(\mathrm{p}<0,01)$.

S : Sekam padi, A : Alang-alang 
ISSN $1978-3000$

terbatas untuk menyerap air. Akibatnya air mengalir ke lantai dan atau menguap ke udara. Penggunaan alang-alang sebagai penutup alas kandang nampaknya mampu menyerap air yang lebih banyak dibandingkan dengan sekam padi. Nampak kadar air perlakuan alang-alang meningkat lebih cepat dibandingkan perlakuan sekam padi. Data menunjukkan semakin tebal bahan penutup alas kandang, semakin besar pula kemampuannya menyerap air.

Berdasarkan sidik ragam (Tabel 2) terbukti bahwa perlakuan berpengaruh sangat nyata terhadap rataan kadar air litter.

Perlakuan bahan penutup alas kandang berpengaruh sangat nyata $(\mathrm{p}<0,01)$ terhadap kadar air litter. Berdasarkan uji lanjut (DMRT) terbukti, bahwa perlakuan alang-alang sebagai penutup alas kandang berpengaruh sangat nyata $(p<0,01)$ meningkatkan rataan kadar air dibandingkan perlakuan sekam padi. Hal ini berarti alang-alang lebih mampu menyerap air dibandingkan dengan sekam padi.

Menarik untuk dikaji adalah ketebalan bahan penutup alas kandang berpengaruh tidak nyata terhadap kadar air litter. Hal ini diduga air diserap secara merata ke seluruh bagian bahan sampai jenuh. Kondisi jenuh dari satu bahan yang sama, tentunya mempunyai nilai yang sama.

Pengaruh Perlakuan Terhadap Pertambahan Berat Badan Broiler

Pertambahan berat badan merupakan cerminan dari interaksi faktor genetik, dengan faktor lingkungan (North dkk, 1990). Dalam hal ini iklim mikro berpengaruh sangat besar terhadap kenyamanan broiler di dalam kandang. Kondisi yang nyaman akan berpengaruh positip terhadap pertambahan berat badan. Perkembangan pertambahan berat badan pada berbagai bahan penutup alas kandang, disajikan pada Grafik 3.

Gambar 3. memperlihatkan perkembangan pertambahan berat badan yang relatip sama baik menggunakan penutup alas berbahan sekam padi maupun alang-alang. Nampaknya baik sekam padi maupun alang-alang memberikan respon yang sama baiknya terhadap pertambahan berat badan broiler. Hasil sidik ragam pengaruh perlakuan terhadap pertambahan berat badan broiler disajikan pada Tabel 3.

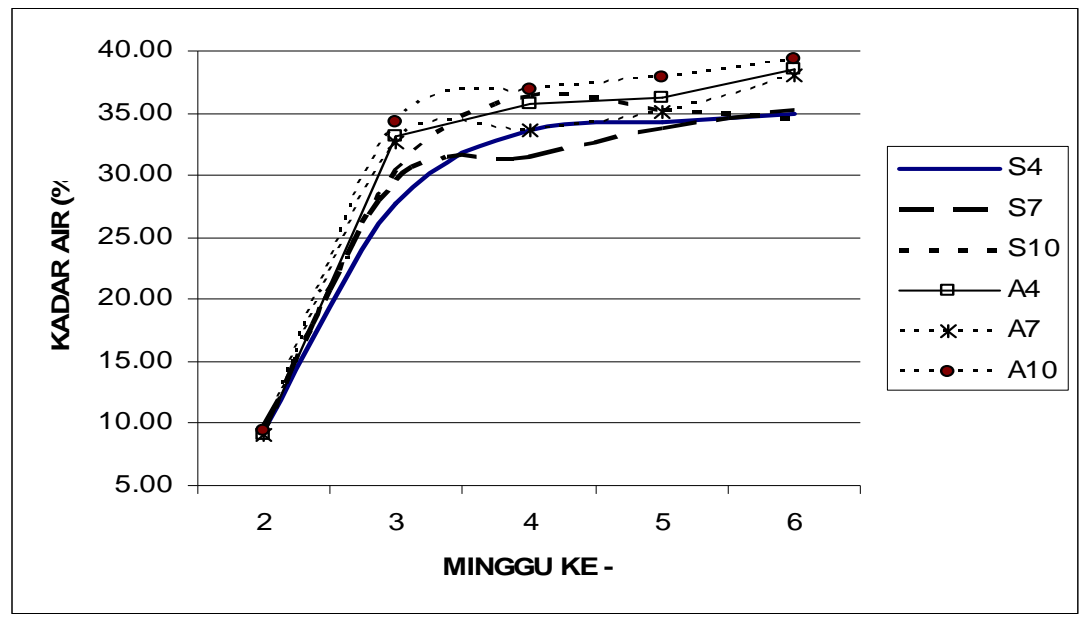

Grafik 2. Peningkatan kadar air (\%) berbagai bahan penutup alas kandang berdasarkan umur broiler. 


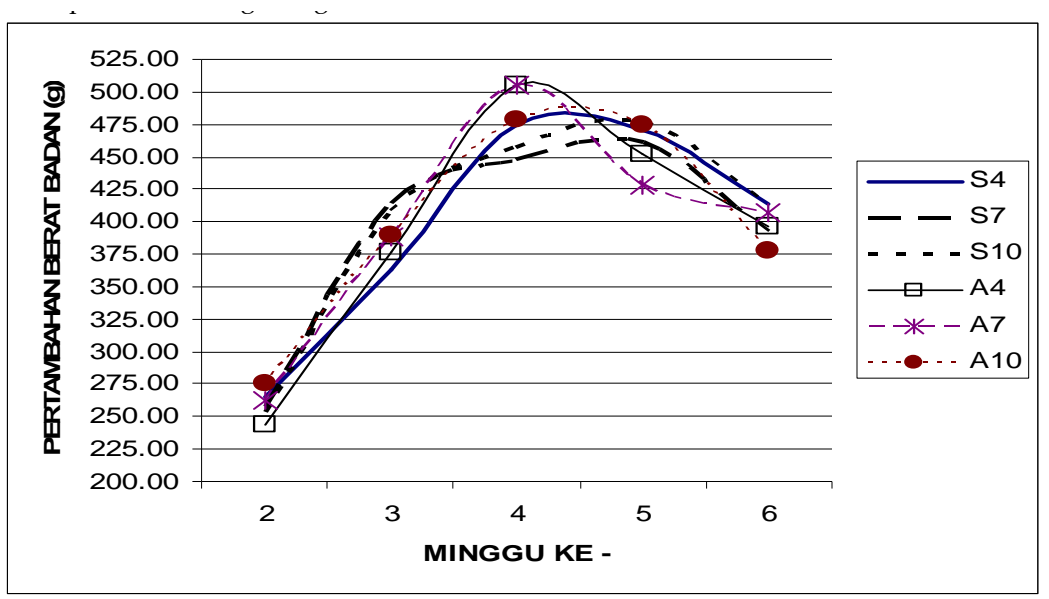

Grafik 3. Perkembangan pertambahan berat badan (g) pada berbagai penutup alas kandang berdasarkan umur broiler.

Tabel 3. Pengaruh Perlakuan Terhadap Pertambahan Berat Badan pada Akhir Penelitian (g).

\begin{tabular}{lrrrrr}
\hline Perlakuan & \multicolumn{4}{c}{ Ulangan } & \multirow{2}{*}{ Rataan } \\
\cline { 2 - 5 } & 1 & 2 & 3 & 4 & \\
\hline S4 & 2009.00 & 1989.00 & 2003.80 & 1944.00 & 1986.45 \\
S7 & 1911.40 & 2062.30 & 2009.20 & 1906.20 & 1972.28 \\
S10 & 2032.40 & 2012.00 & 2051.00 & 1939.80 & 2008.80 \\
A4 & 2036.00 & 1938.00 & 1925.00 & 1992.80 & 1972.95 \\
A7 & 2163.40 & 2006.60 & 1884.20 & 1908.60 & 1990.70 \\
A10 & 1966.20 & 1984.40 & 2032.60 & 2001.50 & 1996.18 \\
\hline
\end{tabular}

Hasil sidik ragam menunjukkan, bahwa perlakuan berpengaruh tidak nyata $(\mathrm{p}>0,05)$ terhadap pertambahan berat badan pada akhir penelitian. Hal ini berarti alang-alang dapat digunakan sebagai penutup alas kandang, tanpa menimbulkan dampak negatip pada pertumbuhan broiler.

\section{SIMPULAN}

Berdasarkan hasil dan pembahasan dapat disimpulkan bahwa alang-alang sepenuhnya dapat menggantikan sekam padi sebagai bahan penutup alas kandang broiler.

\section{DAFTAR PUSTAKA}

Anonim. $2008 . \quad$ Iklim. http:ms.wikipedia.org/wiki/iklim. Juni 2008.

Arifien, M., 2003. Rahasia sukses Memelihara Ayam Broiler di Daerah Tropis. Penebar Swadaya, Jakarta.

Michael, R.D., dan Martopo. 1998. Manusia dan Alang-alang di Indonesia

North, O.M., dan J.D. Bell. 1990. Commercial Chicken Production Manual, 4 th ed. Avi Book Publishing by Van Nostrany Reinholo, New York.

Sarwono, B., 2002. Beternak Ayam Buras. Penebar Swadaya, Jakarta. 